\title{
Virulence and pathogenicity of four Ditylenchus dipsaci populations on sugar beet
}

\author{
Alan Storelli $(1)$ - Sebastian Kiewnick • \\ Matthias Daub (iD) Anne-Katrin Mahlein (ID) \\ Mario Schumann (D) - Werner Beyer (D) \\ Andreas Keiser
}

Accepted: 24 May 2021 / Published online: 28 May 2021

(C) The Author(s) 2021

\begin{abstract}
The stem nematode, Ditylenchus dipsaci, is a severe pest in European sugar beet production. In France, Germany, and Switzerland, D. dipsaci damage in sugar beet varies among specific geographic areas. In this study, the reproduction potential of four geographically distinct $D$. dipsaci populations was determined using sterile carrot disc cultures. In addition, virulence and pathogenicity were investigated in-vivo using sugar beet. No difference was found in the reproduction potential on carrot discs, as well as penetration rate in sugar beet seedlings. The reproduction rate in sugar beet tissue was significantly affected by the $D$. dipsaci population used. The population from Seeland $(\mathrm{CH})$ showed the highest number of nematodes per plant at $60 \mathrm{dpi}$ $(21,071.8 \pm 5340.0)$, compared to the three other
\end{abstract}

A. Storelli $(\bowtie) \cdot$ A. Keiser

School of Agricultural, Forest and Food Sciences HAFL, Bern

University of Applied Sciences BFH, Länggasse 85,

3052 Zollikofen, Switzerland

e-mail: alan.storelli@bfh.ch

\section{S. Kiewnick · M. Daub}

Institute for Plant Protection in Field Crops and Grassland, Julius Kühn Institute (JKI) - Federal Research Centre for Cultivated Plants, Messeweg 11/12, 38104 Braunschweig, Germany

\section{A.-K. Mahlein}

Institute of Sugar Beet Research IfZ, Holtenser Landstrasse 77, 37079 Goettingen, Germany

M. Schumann • W. Beyer

KWS SAAT SE \& Co. KGaA, Grimsehlstrasse 31,

37574 Einbeck, Germany populations contained $3588.6 \pm 3858.3,5136.9 \pm$ 4950.8 , and $3579.7 \pm 5174.2$, respectively. Furthermore, the reproduction rate of $D$. dipsaci was negatively correlated with fresh biomass of sugar beets at $60 \mathrm{dpi}$. Based on these results, the D. dipsaci population "Seeland" is suitable for breeding programs to detect resistance in sugar beet. After selecting candidate genotypes/varieties, these should be further evaluated for their field resistance in their targeted growing regions.

Keywords Beta vulgaris · Carrot disc rearing . Penetration · Reproduction · Resistance breeding

\section{Introduction}

The stem and bulb nematode Ditylenchus dipsaci (Kühn, 1857) Filipjev 1936 is an obligate endoparasite with more than 500 host plants and ranking in the top 10 of plant-parasitic nematodes worldwide (Jones et al., 2013; Sturhan \& Brzeski, 1991). This nematode is highly pathogenic on onion (Allium cepa L.), garlic (Allium sativum L.), narcissus (Narcissus spp.), alfalfa (Medicago sativa L.), and clover (Trifolium spp.) (Boelter et al., 1985; Grandison, 1965; Siti et al., 1982; Windrich, 1986; Yuksel, 1960). The host range of D. dipsaci varies among biological races which represent a species complex (Subbotin et al., 2005; Sturhan et al., 2008). Ritzema Bos (1888) was the first to observe host preferences of different $D$. dipsaci populations. Later, up to 30 biological races were determined by their host preferences (Bovien, 1955; Seinhorst, 1957; 
Sturhan \& Brzeski, 1991). Eriksson (1965) defined biological races as populations distinguished by host preference but not morphologically. He pointed out the races' ability to interbreed and de facto the impossibility of being considered as different species. While some biological races are polyphagous, some are specific to a limited number of plant species as the red clover race (Webster, 1967). The reproduction of polyphagous races varies greatly among host plant species (Whitehead et al., 1987). Qiao et al. (2013) and Poirier et al. (2019) reported distinct genotypes among D. dipsaci populations within a geographic region and between neighboring farms. Esquibet et al. (1998) succeeded to molecularly distinguish the species $D$. dipsaci sensu lato from the giant race D. gigas, recently singled out as new species (Vovlas et al., 2011). To date, molecular analyses do not distinguish the biological races of $D$. dipsaci, while the chromosome number may vary among the races (D'Addabbo Gallo et al., 1982). In this study, the term "population" is reflecting different geographic origins without taking host plant references into account.

Fields may be composed of populations with diverging genetic characters that can interbreed (Bovien, 1955). Eriksson (1965) reported fertile polyphagous progenies of interbreeding between the red clover and lucerne races. Interbreeding can occur under natural conditions in plants contaminated by individuals of different biological races (Janssen, 1994). However, the red clover (Trifolium pratense L.), white clover (Trifolium repens L.), and lucerne races may distinguish themselves from polyphagous races by frequent failure of fertile progenies (Eriksson, 1974).

In Europe, D. dipsaci is an important threat for sugar beet (Beta vulgaris L.) (Dewar \& Cook, 2006; Leipertz, 2007). In Germany and Switzerland, some major sugar beet growing regions are particularly affected by the stem and bulb nematode (Leipertz, 2007; Storelli, Keiser, et al., 2021a). Its penetration on sugar beet seedlings leads to the dissolution of the middle lamellae and swelling of the hypocotyl (Duncan \& Moens, 2013; Madani et al., 2015). Later in the growing season, bacterial and fungal pathogens introduced by D. dipsaci engender rotting of the sugar beet crown (Hillnhütter et al., 2011; Kühnhold, 2011; Storelli et al., 2020). To date, no resistant cultivars towards D. dipsaci are available to farmers (Storelli, Minder, et al., 2021b). Leipertz (2007) and Kühnhold (2011) reported evidence for tolerance of sugar beet cultivars toward crown rot. Variations in the sensitivity of cultivars towards crown rotting were observed among geographic regions in France, Germany, and Switzerland (Leipertz \& Valder, 2017, 2018, 2020).

In this study, the term virulence refers to the ability of a nematode population to reproduce in a plant, whereas pathogenicity refers to the level of damage inflicted to the host plant (Müller, 1989; Perry \& Moens, 2013; Shaner et al., 1992). Variations in the pathogenicity of D. dipsaci populations challenge breeders in their search for resistant cultivars. Ditylenchus dipsaci populations have been shown virulent to cultivars of alfalfa, white clover, and faba bean (Vicia faba L.), previously described as resistant towards $D$. dipsaci populations from other geographic origins (Elgin et al., 1977; Plowright et al., 2002; Whitehead, 1992). Therefore, breeders should consider the pathogenicity and virulence of nematode populations from target regions for commercial cultivars right when choosing the reference population at the start of the breeding process.

This study determines the virulence and pathogenicity of four representative $D$. dipsaci populations from the regions of Aisne (FR), Franconia (DE), Rhineland (DE), and Seeland (CH). Initial levels of virulence were assessed using a standardized carrot disc in-vitro assay. Furthermore, the $D$. dipsaci populations were evaluated in-vivo concerning the penetration rate, virulence, and pathogenicity toward sugar beet seedlings.

\section{Materials and methods}

General methods

Carrots used for $D$. dipsaci rearing were surface sterilized by soaking them for $40 \mathrm{~min}$ in $1 \% \mathrm{NaOCl}$-solution $(w / w)$. Carrots were then rinsed with sterile demineralized water, transferred to a clean bench (HS 18, Kendro Laboratory Products, Germany), and peeled under sterile conditions (Kühnhold et al., 2006). After removing end parts, carrots were cut into three cylinders, which were transferred into a 500-ml sterile glass bottle. After 15 days of incubation in the dark at room temperature, the carrot disc callus was ready for nematode inoculation. A suspension of $D$. dipsaci (juvenile and adult stages) was centrifuged ( $3500 \mathrm{rpm}, 5 \mathrm{~min}$ ) and washed three times with sterile demineralized water. Afterward, they were re-suspended for $30 \mathrm{~min}$ in a sterile antibiotic solution containing $0.1 \%$ streptomycin 
sulfate $(w / v)$ and $0.1 \%$ amphotericin-B (w/v), and finally washed twice with sterile demineralized water (Kühnhold et al., 2006). The nematodes were then inoculated on the surface sterilized carrot disc callus with 50 nematodes per cylinder and incubated for 45 days in the dark at $20 \pm 2{ }^{\circ} \mathrm{C}$ (Storelli, Keiser, et al., 2021a). Nematodes were extracted from carrot discs for $24 \mathrm{~h}$ using Oostenbrink dishes and collected on a $20 \mu \mathrm{m}$ mesh sieve. The nematodes were then stored in the dark at $6-8{ }^{\circ} \mathrm{C}$ for $24 \mathrm{~h}$ until the start of the new experiment.

Untreated sugar beet seeds were sown in $200-\mathrm{ml}$ plastic pots filled with $180 \mathrm{ml}$ non-sterile sieved loess soil/sand/compost mixture $(1 / 1 / 1)(v / v / v)$. The paternal line 'DIT_006' of the cv. BELLADONNA KWS, previously shown to be susceptible to $D$. dipsaci induced crown rot (Leipertz \& Valder, 2020), was used to determine the penetration rate and reproduction potential of D. dipsaci populations in sugar beet. Two seeds were sown per pot and after the first plant's emergence, all following emerging plants were removed to ensure only one seedling per pot. The plants were covered with a Plexiglas mini-glasshouse and regularly watered to maintain a suitable soil moisture allowing nematode movement throughout the duration of the experiment. At 8 days post-planting (dpp), 1000 nematodes were inoculated in $500 \mu \mathrm{l}$ into two 1-cm deep holes (diam. $3 \mathrm{~mm}$ ) approx. $1.5 \mathrm{~cm}$ from the center of the pot (Storelli, Keiser, et al., 2021a).

Isolation, extraction, and maintenance of nematode populations

The four $D$. dipsaci populations investigated were originally obtained from either infested soil or sugar beets, respectively. The nematode population from the Seeland region was extracted from the hypocotyl of infested sugar beets (cv. SAMUELA KWS) collected in 2015. Nematodes were extracted for $24 \mathrm{~h}$ using the Oostenbrink dish technique (European and Mediterranean Plant Protection Organization, 2013). The three $D$. dipsaci populations from Franconia, Rhineland, and Aisne were extracted in 2018 from infested field soils after the sugar beet harvest as described above. Ditylenchus dipsaci was identified with the aid of an optical microscope at 40x magnification using morphological characteristics described in taxonomic literature (European and Mediterranean Plant Protection Organization, 2017). Approximately 300 fourth-stage juveniles (J4) and adult stages of
D. dipsaci were hand-picked, transferred to $1.5-\mathrm{ml}$ microcentrifuge tubes, and incubated for 45 days on carrot discs after surface sterilization as mentioned above. Nematodes were then extracted for $24 \mathrm{~h}$ as mentioned above.

Virulence of Ditylenchus dipsaci populations on carrots discs

Initial virulence of the four $D$. dipsaci populations was determined using an in-vitro assay with carrot discs. Fifty nematodes (J4 and adult stage) were inoculated per carrot disc and incubated for 45 days as described above. After Oostenbrink extraction for $24 \mathrm{~h}$, the numbers of eggs, second-and third-stage juveniles ( $\mathrm{J} 2$ and $\mathrm{J} 3$ ), J4, and adults in one reagent bottle containing three carrot discs were determined separately using an optical microscope at 40x magnification. Five reagent bottles were prepared per $D$. dipsaci population, and the experiment was conducted twice.

Infectivity of Ditylenchus dipsaci populations on sugar beet

The penetration rate in the breeding line 'DIT_006' was determined for all four $D$. dipsaci populations. At 15 days post-inoculation (dpi), the sugar beet seedlings were collected, washed, and stained in a plastic beaker containing a $0.1 \%$ acid fuchsin/lactic acid dye solution by heating them twice in a microwave until boiling and subsequently stored at $6{ }^{\circ} \mathrm{C}$ until further use. Stained seedlings were rinsed with tap water to remove the dye solution. After a maceration $(6500 \mathrm{rpm}, 15 \mathrm{~s})$ of the seedlings in $30 \mathrm{ml}$ of tap water using an Ultra Turrax blender (T25 basic/S25 N - 18 G, IKA Labortechnik, Germany) (Kühnhold et al., 2006), the number of D. dipsaci per seedling was determined using a stereomicroscope at $10 \mathrm{x}$ magnification. The experiment was set up in a growth chamber (KBWF 720, Binder GmbH, Germany) at $15 / 8{ }^{\circ} \mathrm{C}$ and a photoperiod of $18 / 6 \mathrm{~h}$ day/ night. The experiment was conducted twice with 10 replicates per population.

Virulence and pathogenicity of Ditylenchus dipsaci populations on sugar beet

Virulence and pathogenicity of the four D. dipsaci populations were determined using the breeding line 'DIT_006'. At $15 \mathrm{dpi}$, the effect of the D. dipsaci 
populations on symptom expression on sugar beet seedlings was determined by assessing the incidence of swollen hypocotyls. At $60 \mathrm{dpi}$, the plants were harvested, total fresh weight determined, and cut into small pieces. The number of nematodes per plant was determined using an optical microscope at 40x magnification after extraction for $24 \mathrm{~h}$ in Oostenbrink dishes (European and Mediterranean Plant Protection Organization, 2013). The experiment was conducted in a growth chamber (KBWF 720, Binder GmbH, Germany) at $15 / 8{ }^{\circ} \mathrm{C}$ and a photoperiod of $18 / 6 \mathrm{~h}$ day/night. For secondary growth of the sugar beets, the plants were transferred, at $15 \mathrm{dpi}$, to a glasshouse at $22 / 15^{\circ} \mathrm{C}$ with a photoperiod of $18 / 6 \mathrm{~h}$ day/night. Nematode reproduction, symptom development, biomass and plant survival was determined in 10 plants per $D$. dipsaci population, and the experiment was replicated twice. Noninoculated plants were used as a control to determine the nematode pathogenicity.

Data analyses

All experiments were arranged in a complete randomized design (CRD). The data from repeated experiments were pooled after confirming the homogeneity of variances between experiments. Analyses of variance were performed to determine the nematode population's effect on their development on carrot discs and sugar beets. As the normal distribution of data was not given, the Kruskal-Wallis rank-sum test was performed to identify significant effects of population on the number of produced nematodes during the rearing process on carrots. A Friedman test determined the effect of the nematode populations on plant survival and symptoms incidence. Tukey test of multiple comparisons of means was performed as posthoc tests. Values show the mean of the standard deviation ( \pm SD). Statistical analyses, as well as graphs, were performed with R (4.04).

\section{Results}

Virulence of Ditylenchus dipsaci populations on carrot discs

The number of nematodes reproduced per carrot disc did not vary among the four $D$. dipsaci populations testet (Table 1). All D. dipsaci populations reproduced well on carrot callus. An average of 111,425.1 $\pm 10,009.9$ nematodes was obtained after 45 days from an initial inoculum of $150 \mathrm{D}$. dipsaci individuals per reagent bottle. The proportion of the different nematode stages varied significantly among the four $D$. dipsaci populations (Table 1). The nematode population from Franconia (DE) produced a greater percentage of eggs $(P<0.05)$ and a lower percentage of $\mathrm{J} 2$ and $\mathrm{J} 3$ $(P<0.01)$ compared to the populations from Rhineland $(\mathrm{DE})$ and Seeland $(\mathrm{CH})$, respectively.

Infectivity of Ditylenchus dipsaci populations on sugar beet

The number of nematodes in sugar beet seedlings at 15 dpi did not vary among the four $D$. dipsaci populations tested, with an average of $22.8 \mathrm{D}$. dipsaci per seedling (Fig. 1). After inoculation with the Franconia population, D. dipsaci was detected in $100 \%$ of the plants at 15 dpi. The remaining populations showed few escapes for the Rhineland and Aisne (F) population (2 plants each) as well as Seeland (1 plant).

Virulence and pathogenicity of Ditylenchus dipsaci populations in sugar beet

The number of nematodes in sugar beets at 60 dpi varied significantly among the four $D$. dipsaci populations (Fig. 2, $P<0.001$ ). While all $D$. dipsaci populations could reproduce on sugar beets, reproduction was significantly higher for Seeland nematodes, with 21,071 \pm 16,020 individuals per plant. At $60 \mathrm{dpi}$, the sugar beets inoculated with nematodes from Aisne, Franconia, and Rhineland contained $3588 \pm 3858,5136 \pm 4950$, and $3579 \pm 5174$ individuals, respectively. The incidence for plants showing reproduction of $D$. dipsaci was $100 \%$, except for the population Aisne, where one plant contained no nematodes.

The nematode populations from Franconia, Rhineland, and Aisne showed a significantly greater percentage of plants with swollen hypocotyls compared to the non-inoculated control (Table $2, P<0.05$ ). The nematode populations significantly affected the sugar beet fresh weight at $60 \mathrm{dpi}$ (Table $2, P<0.0001$ ), with the lowest value recorded after inoculation with the Seeland population. In addition, the population of $D$. dipsaci significantly influenced the plant survival at $60 \mathrm{dpi}$ (Table 2, $P<0.05$ ), with the nematode populations from Franconia and Seeland leading to the lowest percentage of survivors $(70.8 \%)$. 
Table 1 Effect of the Ditylenchus dipsaci population on the number of produced nematodes and the percentage of eggs, second- (J2), third$(\mathrm{J} 3)$, fourth-stage juveniles $(\mathrm{J} 4)$, and adult stages $( \pm \mathrm{SD})$ in a reagent bottle containing three carrot discs incubated for 45 days

\begin{tabular}{lllll}
\hline Nematode population & Nematodes per 3 carrot discs & Eggs (\%) & J2-J3 (\%) & J4-Adult (\%) \\
\hline Aisne (F) & $111,231.0 \pm 76,452.0$ & $17.8 \pm 5.7 \mathrm{ab}$ & $29.4 \pm 6.2 \mathrm{ab}$ & $52.7 \pm 8.2$ \\
Franconia (DE) & $85,885.9 \pm 68,828.9$ & $21.5 \pm 7.9 \mathrm{~b}$ & $23.7 \pm 6.1 \mathrm{a}$ & $54.8 \pm 10.3$ \\
Rhineland (DE) & $116,083.4 \pm 49,111.6$ & $13.9 \pm 4.8 \mathrm{a}$ & $34.7 \pm 7.9 \mathrm{~b}$ & $51.4 \pm 7.3$ \\
Seeland (CH) & $132,500.3 \pm 55,954.3$ & $13.8 \pm 4.0 \mathrm{a}$ & $34.2 \pm 7.7 \mathrm{~b}$ & $52.0 \pm 10.0$ \\
& n.s. & $P<0.05$ & $P<0.01$ & $n . s$. \\
\hline
\end{tabular}

Different letters indicate a significant difference at $P<0.05$, according to the Tukey test of multiple comparisons of means; n.s. $=$ nonsignificant; $(n=10)$

\section{Discussion}

Our study demonstrated variations of virulence and pathogenicity of the different nematode populations on carrot discs and sugar beet. All four $D$. dipsaci populations were able to invade sugar beet seedlings. As the soil inoculation method was applied, sugar beet evidently attracted all four populations. While penetration was similar for the four nematode populations, the Seeland population showed a significantly greater reproduction. This finding correlates with the observation of Elgin et al. (1977), where D. dipsaci populations did not differ in their ability to invade the host plant but differed in reproducing in their host. All four $D$. dipsaci populations did not show a significant variation of nematode incidence, defined by the percentage of plants affected by $D$. dipsaci. In contrast, Whitehead (1984) observed a different percentage of infected lucerne among 11 nematode populations from England. The very few noninfected plants in our experiments were probably due to plants escaping inoculation.
The different nematode populations did significantly influence the fresh weight of infected sugar beet. As the non-inoculated plants showed a significantly higher biomass, we can assume that all populations are pathogenic to sugar beet. Inoculation of the Seeland population resulted in the lowest biomass in comparison to the other populations. Additionally, the Seeland population led to a low percentage of plants surviving nematode infection. These results validate the observations in field trials located in the Seeland region, where crown rotting regularly occurs more severely than in other regions (Leipertz, 2011; Leipertz \& Valder, 2017, 2018, 2020). However, this may also be enhanced through many host plants in the crop rotation. Indeed, the Seeland region is an important vegetable growing region, where it is common to find sugar beets, onions, and carrots in the crop rotation. Similar penetration and symptoms incidence of all four populations at $14 \mathrm{dpi}$, followed by a greater number of nematode and a lower biomass and survival rate of plant inoculated with the Seeland population, suggest the presence of a $D$. dipsaci
Fig. 1 Number of Ditylenchus dipsaci per plant, 15 days postinoculation (dpi) with the four populations Aisne, Franconia, Rhineland, and Seeland. $(n=20)$

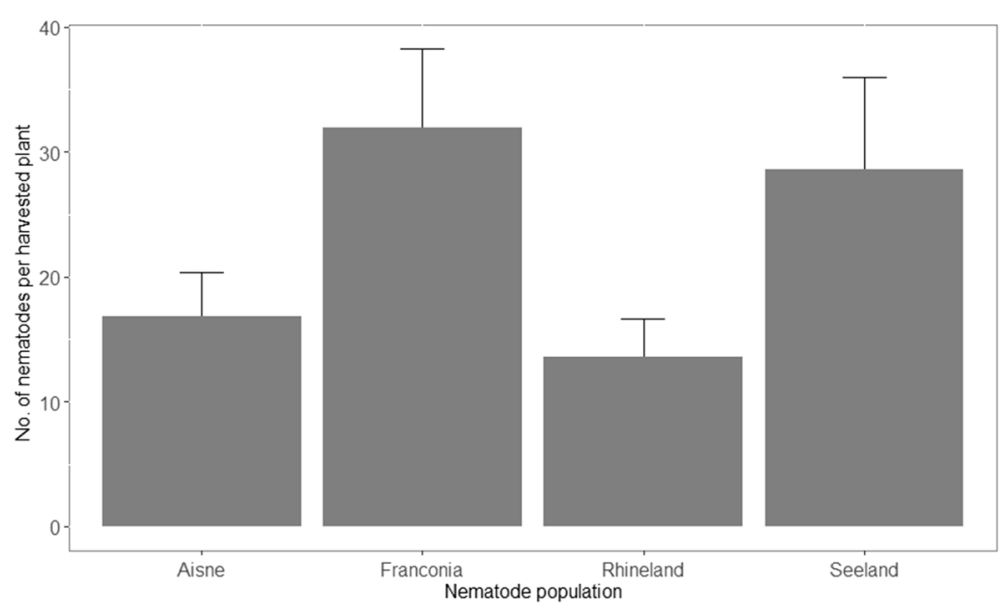


Fig. 2 Number of Ditylenchus dipsaci per plant, 60 days postinoculation (dpi) with the four populations Aisne, Franconia, Rhineland, and Seeland. $(n=20)$. Bars $( \pm$ SD) showing different letters are significantly different according to a Tukey test at $P<0.05(\mathrm{n}=20)$

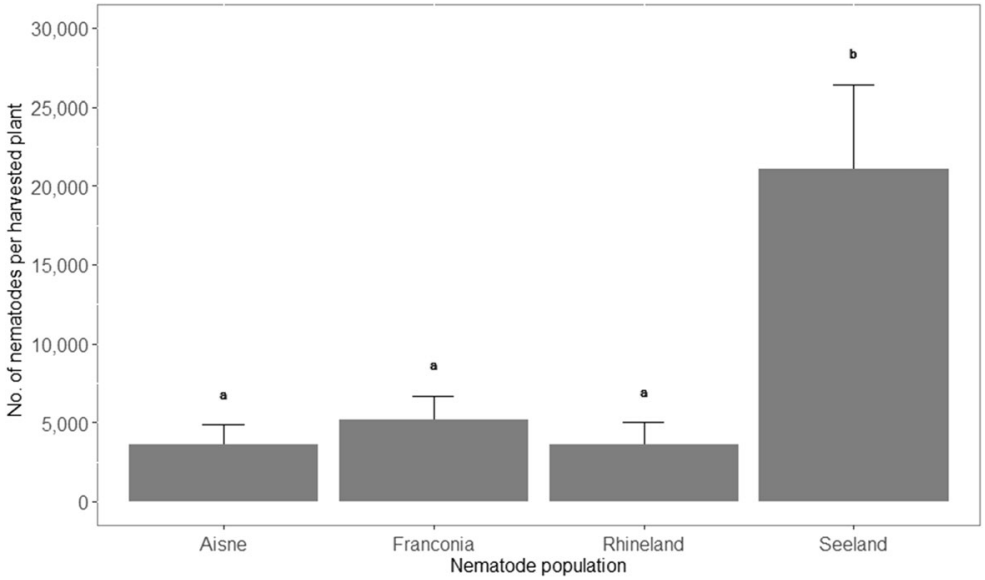

biological race highly adapted to sugar beet in the Seeland.

The $D$. dipsaci population from Seeland may consist of the beet race. As onion is frequently cultivated in the Seeland region, the $D$. dipsaci onion race, which reproduces greatly on sugar beet (Whitehead et al., 1987), may also be the original race of this population. In contrast, the three other populations may come from different races' interbreeding, reducing their reproduction (Janssen, 1994). Indeed, interbreeding can easily occur under natural conditions (Bovien, 1955). In France, $D$. dipsaci mainly infects faba bean and lucerne (Esquibet et al., 1998; Mouttet et al., 2014). The damages on sugar beets are rare in France and not published. This correlates with our study, where the Asine population showed a survival rate similar to non-inoculated plants and a low impact on sugar beet biomass. We assume that the Aisne region's nematode population does probably not belong to the beet race, and its reproduction is de facto lower on sugar beet. Whitehead et al. (1987) observed a lower reproduction of the lucerne and bean races on sugar beet. A D. dipsaci population from the Aisne region proved to be a lucerne race (Whitehead, 1992). Similar can be assumed for the Rhineland population. Indeed, Kotthoff (1950) reported rye (Secale cereale L.) as the main host crop for $D$. dipsaci in this region.

All four populations were able to reproduce on carrot callus. The reproduction was very high on carrots, where the population increased by almost 750 times in 45 days. A previous study performed by the authors of this paper obtained a similar reproduction of the Seeland population on carrot discs (Storelli, Keiser, et al., 2021a). The reproduction was higher than reported from a Canadian population observed by Abolfazl et al. (2017), where the population increased up to 250 times in three months. However, the reproduction may vary greatly depending on the experimental settings. Indeed, Kühnhold et al. (2006) observed high variations of the reproduction in a $D$. dipsaci population from the Rhineland region depending on the incubation period and inoculum level on carrot discs. Although all populations were successfully reared on carrot callus, our study cannot state that carrot is a host plant for each
Table 2 Effect of the

Ditylenchus dipsaci population on the incidence of plants with swollen hypocotyl (\%) at 15 days post-inoculation (dpi), plant fresh weight $(\mathrm{g})$, and survivor plants $(\%)$ at $60 \mathrm{dpi}( \pm \mathrm{SD})$

Different letters indicate a significant difference at $P<0.05$, according to the Tukey test of multiple comparisons of means $(n=20)$

\begin{tabular}{llll}
\hline Nematode population & Swelling incidence $(\%)$ & Plant fresh weight $(\mathrm{g})$ & Survivor (\%) \\
\hline Non-inoculated & $0.0 \pm 0.0 \mathrm{~b}$ & $12.1 \pm 1.8 \mathrm{~d}$ & $100 \pm 0.0 \mathrm{a}$ \\
Aisne (F) & $75.0 \pm 31.9 \mathrm{a}$ & $9.2 \pm 2.5 \mathrm{c}$ & $100 \pm 0.0 \mathrm{a}$ \\
Franconia (DE) & $81.2 \pm 23.9 \mathrm{a}$ & $6.2 \pm 1.6 \mathrm{ab}$ & $66.7 \pm 31.2 \mathrm{~b}$ \\
Rhineland (DE) & $87.5 \pm 14.4 \mathrm{a}$ & $8.1 \pm 2.6 \mathrm{bc}$ & $87.5 \pm 14.4 \mathrm{ab}$ \\
Seeland (CH) & $56.2 \pm 18.5 \mathrm{ab}$ & $5.0 \pm 2.7 \mathrm{a}$ & $70.8 \pm 21.0 \mathrm{~b}$ \\
& $P<0.05$ & $P<0.0001$ & $P<0.05$ \\
\hline
\end{tabular}


D. dipsaci population under natural conditions. Eriksson (1965) demonstrated that $D$. dipsaci populations could reproduce on the callus of non-host plants.

Our study demonstrated that pathogenicity and virulence vary among nematode populations. While the penetration was similar among the four populations, the Seeland population showed a greater reproduction and, thus, a higher virulence on sugar beets than populations from other regions. Therefore, the authors recommend using the D. dipsaci population from Seeland for the selection of resistant or tolerant sugar beet lines in the breeding process. Due to the uncertainty of a mixed composition of $D$. dipsaci races in field populations and differences in virulence and pathogenicity between populations, it is a prerequisite to conduct field trials in the target regions to validate resistance or tolerance towards $D$. dipsaci. This study did not aim to determine the biological race of the four $D$. dipsaci populations. A host preference investigation is, to date, the only way to determine a $D$. dipsaci population's biological race (Poirier et al., 2019). An easy method to determine the biological race of field population would help growers to adapt their crop rotation and reduce nematode pressure by avoiding host plant species.

Acknowledgments The authors thank the seed company KWS SAAT SE \& Co. KGaA (DE), the sugar factory Schweizer Zucker $\mathrm{AG}(\mathrm{CH})$, and the Bern University of Applied Sciences $(\mathrm{CH})$ for their financial support. We would like to further acknowledge the Institut Technique de la Betterave (ITB, France) for providing soil samples from the Aisne region and the Julius Kühn-Institut (JKI, Germany) for providing the German soil samples.

Code availability Not applicable.

Funding Open Access funding provided by Berner Fachhochschule BFH. KWS SAAT SE \& Co. KGaA, Grimsehlstrasse 31, 37574 Einbeck, Germany.

School of Agricultural, Forest and Food Sciences HAFL, Bern University of Applied Sciences BFH, Länggasse 85, 3052 Zollikofen, Switzerland.

Schweizer Zucker AG, Radelfingenstrasse 30, 3270 Aarberg, Switzerland.

Data availability The data that support the findings of this study are available from the corresponding author.

\section{Declarations}

Ethics approval Not applicable.

Consent to participate Not applicable.
Consent for publication All authors give their consent for the publication of the manuscript in the European Journal of Plant Pathology.

\section{Conflicts of interest/competing interests None.}

Open Access This article is licensed under a Creative Commons Attribution 4.0 International License, which permits use, sharing, adaptation, distribution and reproduction in any medium or format, as long as you give appropriate credit to the original author(s) and the source, provide a link to the Creative Commons licence, and indicate if changes were made. The images or other third party material in this article are included in the article's Creative Commons licence, unless indicated otherwise in a credit line to the material. If material is not included in the article's Creative Commons licence and your intended use is not permitted by statutory regulation or exceeds the permitted use, you will need to obtain permission directly from the copyright holder. To view a copy of this licence, visit http://creativecommons.org/licenses/by/4.0/.

\section{References}

Abolfazl, H., Mario, T., \& Robert, H. G. (2017). Monoxenic rearing of Ditylenchus weischeri and D. dipsaci and microplot examination of the host suitability of yellow pea to D. weischeri. Plant Protection Science, 53, 254-264. https://doi.org/10.17221/158/2016-PPS .

Boelter, R. H., Gray, F. A., \& Delaney, R. H. (1985). Effect of Ditylenchus dipsaci on alfalfa mortality, winterkill, and yield. Journal of Nematology, 17(2), 140-144.

Bovien, P. (1955). Host specifity and resistance in plant nematodes. Annals of Applied Biology, 42, 382-390. https://doi. org/10.1111/j.1744-7348.1955.tb02443.x .

D’Addabbo Gallo, M., Morone De Lucia, M. R., Grimaldi De Zio, S., \& Lamberti, F. (1982). Caryo-phenotype relationship in Ditylenchus dipsaci. Nematol. medit., 10, 39-47.

Dewar, A. M., \& Cook, D. A. (2006). Pests. In A. P. Draycott (Ed.), Sugar beet (pp. 316-358, World agriculture series). Oxford, Ames, Iowa: Blackwell Pub.

Duncan, L. W., \& Moens, M. (2013). Migratory endoparasitic nematodes. In R. N. Perry \& M. Moens (Eds.), Plant nematology (2nd ed., pp. 144-178). CABI.

Elgin, J. H., Evans, D. W., \& Faulkner, L. R. (1977). Response of resistant and susceptible alfalfa cultivars to regional isolates of stem nematode 1. Crop Science, 17, 957-959. https://doi. org/10.2135/cropsci1977.0011183X001700060035x .

Eriksson, K. B. (1965). Crossing experiments with races of Ditylenchus Dipsaci on callus tissue cultures. Nematology, 11, 244-248. https://doi.org/10.1163/187529265X00131 .

Eriksson, K. B. (1974). Intraspecific variation in Ditylenchus dipsaci I. Compatibility tests with races. Nematologica, 20, 147-162. https://doi.org/10.1163/187529274X00122 .

Esquibet, M., Bekal, S., Castagnone-Sereno, P., Gauthier, J.-P., Rivoal, R., \& Caubel, G. (1998). Differentiation of normal and giant Vicia faba populations of the stem nematode 
Ditylenchus dipsaci: Agreement between RAPD and phenotypic characteristics. Heredity, 81, 291-298. https://doi. org/10.1046/j.1365-2540.1998.00367.x .

European and Mediterranean Plant Protection Organization. (2013). PM 7/119 (1) nematode extraction. EPPO Bulletin, 43, 471-495. https://doi.org/10.1111/epp.12077 .

European and Mediterranean Plant Protection Organization. (2017). PM 7/87 (2) Ditylenchus destructor and Ditylenchus dipsaci. EPPO Bulletin, 47, 401-419. https://doi.org/10.1111/epp.12433 .

Grandison, G. S. (1965). The stem nematode (Ditylenchus dipsaci ) in clovers in New Zealand (a note). New Zealand Journal of Agricultural Research, 8, 1090-1091. https://doi. org/10.1080/00288233.1965.10423740 .

Hillnhütter, C., Albersmeier, A., Berdugo, C. A., \& Sikora, R. A. (2011). Synergistic damage by interactions between Ditylenchus dipsaci and Rhizoctonia solani (AG 2-2IIIB) on sugar beet. Journal of Plant Diseases and Protection, 118, 127-133. https://doi.org/10.1007/BF03356392 .

Janssen, G. J. W. (1994). The relevance of races in Ditylenchus dipsaci (Kühn) Filipjev, the stem nematode. Fundamental and Applied Nematology, 17(5), 469-473.

Jones, J. T., Haegeman, A., Danchin, E. G. J., Gaur, H. S., Helder, J., Jones, M. G. K., Kikuchi, T., Manzanilla-López, R., Palomares-Rius, J. E., Wesemael, W. M. L., \& Perry, R. N. (2013). Top 10 plant-parasitic nematodes in molecular plant pathology. Molecular Plant Pathology, 14, 946-961. https://doi.org/10.1111/mpp.12057 .

Kotthoff, P. (1950). Die Verbreitung von Ditylenchus dipsaci (Kühn) als Schädling an landwirtschaftlichen Kulturpflanzen in Westfalen. Zeitschrift für Pflanzenkrankheiten (Pflanzenpathologie) und Pflanzenschutz, 57(1), 4-14.

Kühnhold, V. (2011). Investigation on host-parasite interaction between the stem nematode Ditylenchus dipsaci and sugar beet Beta vulgaris and their importance for development of alternative integrated management strategies. . Rheinischen Friedrich-Wilhelms-Universität, Bonn.

Kühnhold, V., Kiewnick, S., \& Sikora, R. A. (2006). Development of an in vivo bioassay to identify sugar beet resistance to the stem nematode Ditylenchus dipsaci. Nematology, 8, 641645. https://doi.org/10.1163/156854106778877875 .

Leipertz, H. (2007). Variationzwischen Zuckerrübensorten und stämmen auf Befall mit Ditylenchus dipsaci. In Deutschen Phytomedizinischen Gesellschaft (DPG) (Ed.), Arbeitskreis Nematologie, Potsdam-Golm, Germany (pp. 187-188).

Leipertz, H. (2011). Variation between sugar beet cultivars and strains on damages caused by Ditylenchus dipsaci: Trial records 2010. Internal Report.

Leipertz, H., \& Valder, S. (2017). Variation between sugar beet cultivars and strains on damages caused by Ditylenchus dipsaci: Trial records 2016. Internal Report.

Leipertz, H., \& Valder, S. (2018). Variation between sugar beet cultivars and strains on damages caused by Ditylenchus dipsaci: Trial records 2017. Internal Report.

Leipertz, H., \& Valder, S. (2020). Variation between sugar beet cultivars and strains on damages caused by Ditylenchus dipsaci: Trial records 2019. Internal Report.

Madani, M., Tenuta, M., Chizhov, V. N., \& Subbotin, S. A. (2015). Diagnostics of stem and bulb nematodes, Ditylenchus weischeri and D. dipsaci (Nematoda:
Anguinidae), using PCR with species-specific primers. Canadian Journal of Plant Pathology, 37, 212-220. https://doi.org/10.1080/07060661.2015.1035754 .

Mouttet, R., Escobar-Gutiérrez, A., Esquibet, M., Gentzbittel, L., Mugniéry, D., Reignault, P., Sarniguet, C., \& CastagnoneSereno, P. (2014). Banning of methyl bromide for seed treatment: Could Ditylenchus dipsaci again become a major threat to alfalfa production in Europe? Pest Management Science, 70, 1017-1022. https://doi.org/10.1002/ps.3745 .

Müller, J. (1989). Zur Definition von Resistenz und anderer Fachbegriffe in der Nematologie. Nachrichtenbl. Deut. Pflanzenschutzd, 41(8/9), 137-139.

Perry, R. N., \& Moens, M. (Eds.). (2013). Plant nematology (2nd ed.). $\mathrm{CABI}$.

Plowright, R. A., Caubel, G., \& Mizen, K. A. (2002). Ditylenchus species. In J. L. Starr, R. Cook, \& J. Bridge (Eds.), Plant resistance to parasitic nematodes (pp. 107-139). CABI.

Poirier, S., Dauphinais, N., van der Heyden, H., Véronneau, P.-Y., Bélair, G., Gravel, V., \& Mimee, B. (2019). Host range and genetic characterization of Ditylenchus dipsaci populations from eastern Canada. Plant Disease, 103, 456-460. https://doi.org/10.1094/PDIS-07-18-1201-RE .

Qiao, Y., Zaidi, M., Badiss, A., Hughes, B., Celetti, M. J., \& Yu, Q. (2013). Intra-racial genetic variation of Ditylenchus dipsaci isolated from garlic in Ontario as revealed by random amplified polymorphic DNA analysis. Canadian Journal of Plant Pathology, 35, 346-353. https://doi.org/10.1080 /07060661.2013.804883 .

Ritzema Bos, J. (1888). L'anguillule de la tige (Tylenchus devastatrix Kühn) et les maladies des plantes dues à ce nématode. Haarlem. https://edepot.wur.nl/494755. Accessed 22 December 2020.

Seinhorst, J. W. (1957). Some aspects of the biology and ecology of stem eelworms. Nematologica, 2, 355-361.

Shaner, G., Stromberg, E. L., Lacy, G. H., Barker, K. R., \& Pirone, T. P. (1992). Nomenclature and concepts of pathogenicity and virulence. Annual Review of Phytopathology, 30, 47-66. https://doi.org/10.1146/annurev.py.30.090192.000403 .

Siti, E., Cohn, E., Katan, J., \& Mordechai, M. (1982). Control of Ditylenchus dipsaci in garlic by bulb and soil treatments. Phytoparasitica, 10, 93-100. https://doi.org/10.1007 /BF02981132.

Storelli, A., Keiser, A., Eder, R., Jenni, S., \& Kiewnick, S. (2020). Evaluation of fluopyram for the control of Ditylenchus dipsaci in sugar beet. Journal of Nematology. https://doi. org/10.21307/jofnem-2020-071 .

Storelli, A., Keiser, A., Kiewnick, S., Daub, M., Mahlein, A.-K., Beyer, W., \& Schumann, M. (2021a). Development of a new in vivo protocol through soil inoculation to investigate sugar beet resistance towards Ditylenchus dipsaci penetration. Nematology, 0, 1-10. https://doi.org/10.1163/15685411bja10069.

Storelli, A., Minder, A., Keiser, A., Kiewnick, S., Daub, M., Mahlein, A.-K., et al. (2021b). Screening of sugar beet prebreeding populations and breeding lines for resistance to Ditylenchus dipsaci penetration and reproduction. Journal of Plant Diseases and Protection. https://doi.org/10.1007 /s41348-021-00483-6

Sturhan, D., \& Brzeski, M. W. (1991). Stem and bulb nematodes, Ditylenchus spp. In W. R. Nickle (Ed.), Manual of Agricultural Nematology (pp. 423-464). CRC Press. 
Subbotin, S. A., Madani, M., Krall, E., Sturhan, D., \& Moens, M. (2005). Molecular diagnostics, taxonomy, and phylogeny of the stem nematode Ditylenchus dipsaci species complex based on the sequences of the internal transcribed spacerrDNA. Phytopathology, 95, 1308-1315. https://doi. org/10.1094/PHYTO-95-1308 .

Vovlas, N., Troccoli, A., Palomares-Rius, J. E., de Luca, F., Liébanas, G., Landa, B. B., Subbotin, S. A., \& Castillo, P. (2011). Ditylenchus gigas n. sp. parasitizing broad bean: A new stem nematode singled out from the Ditylenchus dipsaci species complex using a polyphasic approach with molecular phylogeny. Plant Pathology, 60, 762-775. https://doi. org/10.1111/j.1365-3059.2011.02430.x .

Webster, J. M. (1967). The significance of biological races of Ditylenchus dipsaci and their hybrids. Annals of Applied Biology, 59, 77-83. https://doi.org/10.1111/j.17447348.1967.tb04418.x .

Whitehead, A. G. (1984). Interaction of three lucerne cultivars and eleven English isolates of stem nematode (Ditylenchus dipsaci ), 'lucerne race'. Plant Pathology, 33, 33-37. https://doi.org/10.1111/j.1365-3059.1984.tb00584.x .

Whitehead, A. G. (1992). Sources of resistance to stem nematode, Ditylenchus dipsaci (Kühn) Filipjev, in species of Medicago and Trifolium. Annals of Applied Biology, 120, 73-81. https://doi.org/10.1111/j.1744-7348.1992.tb03405.x .

Whitehead, A. G., Fraser, J. E., \& Nichols, A. J. F. (1987). Variation in the development of stem nematodes, Ditylenchus dipsaci, in susceptible and resistant crop plants. Annals of Applied Biology, 111, 373-383. https://doi. org/10.1111/j.1744-7348.1987.tb01465.x .

Windrich, W. A. (1986). Control of stem nematode, Ditylenchus dipsaci, in narcissus with aldicarb. Crop Protection, 5, 266267. https://doi.org/10.1016/0261-2194(86)90061-X .

Yuksel, H. S. (1960). Observations on the life cycle of Ditylenchus Dipsaci on onion seedlings. Nematologica, 5, 289-296. https://doi.org/10.1163/187529260X00091 . 